\title{
Tensões entre os Visitadores Eclesiásticos e as Irmandades Negras no Século XVIII Mineiro
}

\author{
Alisson Eugênio* \\ Universidade Vale do Rio Doce
}

\section{Resum O}

Trata-sedeuma pesquisa** sobre recriações e vivências culturais de negros que se asso ciavam em irmandades religiosas no século XVIII mineiro. Partindo de elementos culturais apropriados da sociedade escravista, bem como de lugares e tempos negociados com os representantes da ordem social,somados a valores herdados das terras de origem no continente africano, estes indivíduos construíram um mundo próprio nos labirintos da escravidão, no qual deram um outro sentido às suas vidas além da quele que nas M inas Gerais para elesjá estava predeterminado ( ser escravo). Tal sentido estava relacionado em suas festas devocionais e eram vivenciadas em um contexto de uma sociabilidade tensa e solidária.

Palavras-chave:irmand ades negras; visitadores eclesiásticos; festas religiosas.

\section{ABSTRACT}

This articleemphasizes theblack cultural experiences inside the religious brotherhoods in M inas Gerais during the XVIII century. These people built their own world linking cultural elements of the Brazilian slavery society to the African values and beliefs. Thefore,they gave a different meaning to their lives besides that to which they were condemnend (to be a slave). This meaning was related to their devotional feasts lived in a context of tense and fraternal sociability. Keywords: black brotherhoods; ecclesiastic visitors; religious feasts. 
Estando em visita nesta freguesia de Santo Antônio do Itatiaia, comarca de Ouro Preto, os irmãos da Irmanda dedeN ossa Senhorado Rosário eSão Benedito nosapresentou estelivro de contas, evendo o que nele se acham, havemos por incapaz para se fazerem as festas com tanta solenidade quando se vê pelas despesas que são feitas, consumindo nelas o rendimento da irmandade,ficando os irmãos sem sufrágios anuais, não sendo ereto para o proveito das almas dos que falecem, e sim para a ostentação humana, pelo qual só éque fazem tantos festejos.

Frei João da Cruz, $1742^{1}$

As relações vivenciadas pelos agentes eclesiásticos e as irmandades religiosas de escravos e libertos no período colonial mineiro foram marcadas por uma gama complexa de práticas diversas que oscilavam entre negociação e ameaças, ou o acordo e a desobediência se tomarmos as festas devocionais que os irmãos negros organizavam para homenagear suas devoções catól icas anualmente, como referência para analisarmos uma daquelas relações.

As irmandades religiosas eram regidas por um estatuto interno ( Com34 promisso), o qual era aprovado pela igreja e pelo Estado para que elas pudessem funcionar legalmente, composto por uma série de artigos que definiam suas obrigações, o perfil de seus associados e os direitos e deveres destes. Para tanto, elas dependiam de uma receita mínima de forma que pudessem cobrir as despesas com a manuten ção de um capelão, da própria capela, da assistência funerária e da organização das festas devocionais, além de outras funções.

Quando os visitadores eclesiásticos enten diam que as associações religiosas estavam enfatizando as festas e cuidando mal das outras atividades, para as quais fizeram um "compromisso" com seus associados e com a própria I greja, eles chamavam a atenção de suas mesas diretoras e as orientavam no sentido de distribuírem melhor os seus gastos.

Este procedimento dos agentes episcopais poderia recair sobre as irmandades de um modo geral, desde que elas não cumprissem a contento, no entender de tais agentes, o seu "compromisso" para o qual foram confirmadas perante a legislação da I greja e do Estado. Porém, até onde pudemos consultar, as confrarias negras foram as que mais sofreram advertências, pois (segundo os relatórios produzidos pel os visitadores eclesiásticos, após consultarem os registros de suas receitas e despesas) el as faltavam com o cumprimento obrigatório da celebração de missas em intenção das almas de seus irmãos falecidos. $O$ visitador Caetano Furtado de M endonça, em visita à Irmandade de Nossa Senhora do Rosário de Casa Branca, curato pertencente à freguesia 
do Pilar de Ouro Preto, durante o ano de 1741, por exemplo, lembrou aos seus associados que "o quinto capítulo do compromisso desta Irmandade ordena que em cada Domingo se diga uma missa pelos irmãos vivos e defuntos", e constando-Ihe que eles não cumpriram tal preceito, por fal ta de registro dos mesmos, determinou "que se apresente termo de certidão de como se despenderam as ditas missas e as do ofício do dia oito de novembro (cuja) conta da despesa não consta al guma feita" 2 .

Em 1738, o visitador M anuel da Costa Braga, três anos antes da visita mencionada anteriormente, ao anal isar o orçamento anual daquela mesma confraria, surpreendeu-se com o que apurou: "devendo atender a carência desta irmandade, carente de tudo quanto serve para as despesas, e coisas mais convenientes ignoras, é impossível que gastem tanto ouro em festas, como se vê no gasto delas" 3 .

Em 1748, um outro visitador indo à mesma associação religiosa, e após apurar o mesmo problema que seus colegas anteriormente tentaram resolver, informa:

(...) no capítulo seis do compromisso desta I rmandade consta a obrigação de mandar dizer sete missas pelas almas de cada irmão que falecer; e porque vistas as certidões do Livro de Contas se não acha uma certidão que conste estar algum Irmão falecido satisfeito com as sete missas; mandamos os oficiais desta I rmandade que satisfaçam (as missas pendentes) em seis meses correntes a partir da data deste; e tudo sob pena de que não o cumprindo, o Pároco não admita auto al gum da Irmandade, nem nas festividades, enquanto não mostrarem que satisfizeram as ditas missas4.

No início dos anos oitenta, quando os funcionários régios passaram a visitar o balanço do orçamento anual das associações religi osas, Tomás Antônio Gonzaga, ao se debruçar sobre os registros da confraria mencionada anteriormente, reclamou que suas

(...) contas não estão como devem estar, pois não aparecem recibos que as justifiquem; e meu antecessor já mandou que todas as irmandades tenham livros, onde se lancem todos os recibos da despesa que se fizer, assinados pel as pessoas que receberam do tesoureiro qualquer quantia; (e por isso) eu não aprovarei mais despesa al guma, que não vier acompanhada desta prova ${ }^{5} .$.

Pelos dados apresentados acima, podemos perceber, em primeiro lugar, a recorrência de um discurso repressor que, na verdade, não se fazia cumprir. O primeiro visitador averiguou que a associação não registrava os gastos com 
missas às al mas do purgatório (se é que el a gastou alguma quantia com esse precei to cristão) e ordenou-Ihe que o fizesse. 0 segundo agente eclesiástico citado já havia se surpreendido (três anos antes do outro ter apurado o problema da ausên cia de registros das ditas missas) com a "quantidade de ouro gasto em suas festas", não obstante a carência financeira da irmandade visitada que, segundo ele, "coisas mais convenientes ignoras". 0 terceiro representante da Sé ameaçou a desobediente confraria com a não-aprovação das licenças para seus autos (procissões ou outras manifestações "públicas", "nem das festividades"), ao constatar que não havia nenhum registro feito relativo à satisfação dos sufrágios aos falecidos. 0 quarto, já representante do Estado, reclamou de um problema semelhante; isso nos idos dos anos oitenta, após quase meia década de visitação àquel a agremiação. Assim, a desobediência daquela associação negra perpassou, no tempo e no espaço, diferentes poderes: o da Sé do Rio de Janeiro, o da Sé de Mariana eo da Coroa, de tal forma que poderíamos concluir o seguinte: os mecanismos e práticas de controle sobre as confrarias negras, relativos ao enquadramento delas no quadro de valores da cultura religiosa dominante, tiveram seus limites, porque, por um lado, os agentes eclesiásticos e da administração régia não tinham co mo vigiar o tempo inteiro as ações dos confrades, e por outro, a religiosidade dos escravos elibertos era um dos al icerces do mundo que eles construíram nos labirintos da ordem, em que a sua existência tinha sentido.

Tomando duas outras associações religiosas, as I rmandades de N ossa Senhora do Rosário e de São Benedito do Itatiaia (curato também situado na freguesia do Pilar de Ouro Preto), percebemos que elas também desobedeceram às determinações e contrariaram interesses da Sé de forma recorrente ao longo do século XVIII.

O visitante frei João da Cruz, em 1742 em visita (coordenada pela Sé do Rio de Janeiro) àquelas associações, apurou que elas "consumiam o seu rendimento para fazerem festa com tanta solenidade" (ver epígrafe deste capítulo), entendendo "serem incapazes" de assim proceder pelo fato de "seus irmãos falecidos não estarem satisfeitos com os sufrágios anuais", concluindo que suas atividades eram canalizadas "para a ostentação humana e não para o proveito das al mas". Diante desta contestação, ele ordenou às mesas diretoras daquelas confrarias que

(...) não façam mais festas da irmandade com música, armação, sermões,nem senhor exposto, e somente poderão fazer e festejar a Senhora do Rosário com uma missa cantada, e outra a São Benedito, e com o rendimento da irmandade satisfaçam os sufrágios e ofícios pel os irmãos defuntos, evitando as despesas supérfluas que não servem de utilidade para a irmandade ${ }^{6}$. 
Esse visitador entendeu que as festas consumiam recursos excessivos das associações que ele visitou, e por isso tentou reduzi-las a um rito litúrgico ( composto por uma missa, durante a qual um conjunto de cantos era apresentado pelo sacerdote e pelo coro), sem toda aquel a solenidade que exigia sermão, decoração da capela, músicos, foguetório, entre outras coisas. No entanto, ao que parece, suas determinações não foram respeitadas, pois ( entre as suas visitas e a que comentamos a seguir) os oficiais daquelas irmandades continuaram fazendo seus festejos devocionais com tudo aquilo que lhes havia sido proibido?.

Em 1761, o doutor José dos Santos, cônego da Sé de M ariana e reitor do seminário da mesma cidade, atuando como visitador-geral na região deVila Rica, em visita àquelas mesmas confrarias festeiras, relatou que elas não mudaram seus comportamentos,ameaçando-as com a proibição daquilo que lhe parecia mais significativo entre os seus associados:

(...) enquanto não satisfizerem ao provimento de sua Excelência Reverendíssima e ao meu da visita passada, o Reverendo Pároco não consinta fazer festa al guma, sem primei ro apresentarem certidões que constem a satisfação dos sufrágios de todos os Irmãos defuntos, no que o mesmo Reverendo Pároco, averiguando pelo modo possível, superintenderá quanto são os ditos Irmãos (cujos sufrágios estão pendentes), no que lhe encarrego gravíssimamente a sua consciência (em real izar tal averiguação), e achando serem eles muitos e muito grave a despesa que deverão fazer com as missas e sufrágios dos ditos I rmãos, enão podendo satisfazer todas integral mente; Ihes arbitrará a quantidade das missas que deverão mandar dizer antes da festa,para que dessa sorte se possa acudir ao culto divino e aos sufrágios dos I rmãos, pois tem mostrado a experiência que nesta Irmandade se não fazem festas não contribuem os Irmãos com suas esmolas;e este provimento será lido pelo Reverendo Pároco em todos os Domingos e Dias Santos sob pena de condenação maior ${ }^{8}$.

Notem que no discurso deste visitador há uma passagem que embasa parte das argumentações ensaiadas neste trabal ho: de acordo com suas próprias palavras, "tem mostrado a experiência que se não fazem festas não contribuem os I rmãos com suas esmolas". O agente eclesiástico que chegou a essa conclusão ( na condição de cônego da Sé de M ariana, reitor do Seminário dessa mesma cidade e visitador geral de suas freguesias) , parece ter tido experiência demais para produzir tal discurso. N esse sentido, isso e os dados que apresentamos anteriormente nos levam a crer que a festa ocupou um lugar central no conjunto das atividades das associações religiosas (pelo menos nas dos negros) e, por exten são, na existência de seus associados, o que justifica a 
quantia significativa que eles empenhavam do orçamento anual de suas confrarias na organização de seus rituais de devoção lúdica.

Esta constatação fica mais evidente se tomarmos como referência não só os relatos dos visitadores, mas também o Registro de Receitas e D espesas das irmandades que eles visitaram. Tomemos como exemplo aquelas mesmas confrarias cujos gastos com festas devocionais foram repreendidos em várias visitas diocesanas (ver as tabelas nas duas próximas páginas).

Em ambas as séries podemos constatar que as festas consumiam uma significativa quantidade de recursos financeiros de suas associações religiosas, mesmo quando a curva das receitas e despesas passava a apresentar uma trajetória descendente, já no contexto da crise da economia mineradora. Em face desse fato, caberia perguntar: por que tais associações de escravos elibertos gastavam tanto com seus rituais de devoção lúdica?

0 destaque dado às festas devocionais pode ser um exemplo de uma vivência rel igi osa,característica da cultura barroca mineira (mas não só dela), marcada pelo prazer em contemplar a exuberância das imagens, dos incensos, das músicas, dos sermões e das procissões com badaladas de sinos e queimação de fogos de artifício. No caso das irmandades negras, tal destaque pode estar relacionado também com a própria existência de seus associados, para os quais os festejos dedicados às suas devoções poderiam representar um ideal oposto ao mundo do cativeiro, o que talvez ajudaria os confrades negros a construírem uma outra forma de interpretação de seus cotidianos baseados nas festividades.

Uma outra pergunta que se impõe, em face do destaque que as festas tiveram ao longo da segunda metade do século XVIII no orçamento anual daquelas irmandades, está relacionada à não-satisfação integral da quantidade de missas que elas deveriam pagar para o sufrágio das almas de seus associados quando faleciam. Com isso, elas estavam negando a noção do purgatório e, por extensão, os rituais necessários para o resgate dos mor tos que nele esperavam pela remissão dos pecados?

Esta questão demandaria uma extensa pesquisa e os dados de que dispomos neste trabalho não permitem a elaboração de uma resposta bem sustentada empiricamente. $M$ as, como hipótese, podemos dizer que o problema não era tanto com a crença (ou não) no purgatório, e sim com os gastos que deveriam ser feitos para vivenciá-la, os quais eram canalizados para os cofres das paróquias. Isso não quer dizer que a questão se resuma apenas em um fator financeiro, pois a sua complexidade está justamente no fato de que os negros poderiam acreditar no purgatório, mas também não abriram mão da relação com os seus ancestrais a partir de rituais fúnebres recriados de suas heranças culturais africanas, como veremos mais à frente. 


\begin{tabular}{|c|c|c|c|c|c|c|}
\hline \multicolumn{4}{|c|}{$\begin{array}{c}\text { BALANÇO DE RECEITAS } \\
\text { E DESPESAS }\end{array}$} & \multicolumn{3}{|c|}{$\begin{array}{l}\text { PERCENTUAL DE GASTOSCOM } \\
\text { FESTAS DA TABELA AO LADO }\end{array}$} \\
\hline ANO & $\begin{array}{l}\text { RECEITA } \\
\text { ANUAL }\end{array}$ & $\begin{array}{l}\text { DESPESA } \\
\text { ANUAL }\end{array}$ & $\begin{array}{c}\text { GASTO } \\
\text { C/FESTAS }\end{array}$ & ANO & $\begin{array}{c}\text { RECEITA } \\
\text { ANUAL(\%) }\end{array}$ & $\begin{array}{r}\text { DESPESA } \\
\text { ANUAL(\%) }\end{array}$ \\
\hline 730 & 286 & 370 & 193 & 1730 & 67,48 & 52,16 \\
\hline 1731 & 286 & 370 & 197 & 1731 & 68,88 & 53,24 \\
\hline 1732 & - & - & 172 & 1732 & - & - \\
\hline 1733 & 290 & 290 & 153 & 1733 & 52,76 & 52,76 \\
\hline 1734 & 199 & 193 & - & 1734 & - & - \\
\hline 1735 & 206 & 221 & 101 & 1735 & 49,03 & 45,70 \\
\hline 1736 & 199 & 191 & 121 & 1736 & 60,80 & 63,35 \\
\hline 1737 & 268 & 236 & 165 & 1737 & 61,57 & 69,92 \\
\hline 1738 & 130 & 102 & - & 1738 & - & - \\
\hline 1739 & 140 & 140 & 44 & 1739 & 31,43 & 31,43 \\
\hline 1740 & 251 & 250 & 108 & 1740 & 43,03 & 43,20 \\
\hline 1741 & 329 & 329 & 132 & 1741 & 40,12 & 40,12 \\
\hline 1742 & 287 & 287 & 167 & 1742 & 58,19 & 58,19 \\
\hline 1743 & 161 & 264 & - & 1743 & - & - \\
\hline 1744 & 162 & 241 & - & 1744 & - & - \\
\hline 1745 & 113 & 113 & 44 & 1745 & 38,94 & 38,94 \\
\hline 1746 & 99 & 99 & 66 & 1746 & 66,67 & 66,67 \\
\hline 1747 & 102 & 102 & 68 & 1747 & 66,67 & 66,67 \\
\hline 1748 & 66 & 66 & 38 & 1748 & 57,58 & 57,58 \\
\hline 1749 & 122 & 122 & 52 & 1749 & 42,62 & 42,62 \\
\hline 1750 & 201 & 171 & 84 & 1750 & 41,79 & 49,12 \\
\hline 1751 & 132 & 138 & 54 & 1751 & 40,91 & 39,13 \\
\hline 1752 & 114 & 114 & 62 & 1752 & 54,39 & 54,39 \\
\hline 1753 & 128 & 198 & 111 & 1753 & 86,72 & 56,06 \\
\hline 1754 & 201 & 170 & 122 & 1754 & 60,70 & 71,76 \\
\hline 1755 & - & - & - & 1755 & - & - \\
\hline 1756 & 266 & 256 & 143 & 1756 & 53,76 & 55,86 \\
\hline 1757 & & & & 1757 & - & - \\
\hline 1758 & 154 & 176 & 91 & 1758 & 59,09 & 51,70 \\
\hline$\underline{1759}$ & & & & 1759 & - & - \\
\hline 1760 & 245 & 225 & 108 & 1760 & 44,08 & 48,00 \\
\hline 1761 & 146 & 164 & 123 & 1761 & 84,25 & 75,00 \\
\hline 1762 & - & - & - & 1762 & - & - \\
\hline 1763 & 206 & 200 & 112 & 1763 & 54,37 & 56,00 \\
\hline 1764 & - & - & - & 1764 & - & - \\
\hline 1765 & 172 & 166 & 69 & 1765 & 40,12 & 41,57 \\
\hline 1766 & 275 & 207 & - & 1766 & - & - \\
\hline 1767 & - & - & - & 1767 & - & - \\
\hline 1768 & 229 & 172 & 82 & 1768 & 35,81 & 47,67 \\
\hline 1769 & 293 & 267 & 45 & 1769 & 15,36 & 16,85 \\
\hline 1770 & 161 & 134 & 59 & 1770 & 36,65 & 44,03 \\
\hline 1771 & 146 & 82 & 62 & 1771 & 42,47 & 75,61 \\
\hline 1772 & 230 & 106 & 65 & 1772 & 28,26 & 61,32 \\
\hline 1773 & 203 & 65 & - & 1773 & - & - \\
\hline
\end{tabular}




\begin{tabular}{|c|c|c|c|}
\hline \multicolumn{4}{|c|}{$\begin{array}{c}\text { BALANÇO DE RECEITAS } \\
\text { E DESPEESAS }\end{array}$} \\
\hline ANO & $\begin{array}{c}\text { RECEITA } \\
\text { ANUAL }\end{array}$ & $\begin{array}{c}\text { DESPESA } \\
\text { ANUAL }\end{array}$ & $\begin{array}{c}\text { GASTO } \\
\text { C/FESTAS }\end{array}$ \\
\hline 1768 & 127 & 123 & 50 \\
\hline 1769 & 127 & 142 & 64 \\
\hline 1770 & 164 & 151 & 62 \\
\hline 1771 & 125 & 160 & 62 \\
\hline$\underline{1772}$ & 154 & 153 & 64 \\
\hline 1773 & - & - & - \\
\hline$\underline{1774}$ & 165 & 132 & 50 \\
\hline$\underline{1775}$ & 150 & 138 & 57 \\
\hline$\underline{1776}$ & 122 & 108 & 47 \\
\hline 1777 & 162 & 127 & 40 \\
\hline$\underline{1778}$ & - & - & - \\
\hline 1779 & 138 & 99 & 46 \\
\hline$\underline{1780}$ & 123 & 120 & 38 \\
\hline$\underline{1781}$ & - & - & - \\
\hline 1782 & 144 & 112 & 46 \\
\hline 1783 & 144 & 120 & 37 \\
\hline$\underline{1784}$ & 55 & 53 & 13 \\
\hline 1785 & 78 & 86 & 41 \\
\hline$\underline{1786}$ & 93 & 85 & 41 \\
\hline$\underline{1787}$ & 107 & 95 & 45 \\
\hline$\underline{1788}$ & 91 & 90 & 45 \\
\hline 1789 & - & - & - \\
\hline$\underline{1790}$ & 77 & 92 & 51 \\
\hline 1791 & 84 & 83 & 31 \\
\hline 1792 & 84 & 84 & 50 \\
\hline
\end{tabular}

\begin{tabular}{|c|c|c|c|}
\hline \multicolumn{4}{|c|}{$\begin{array}{c}\text { BALANÇO DE RECEITAS } \\
\text { E DESPESAS }\end{array}$} \\
\hline ANO & $\begin{array}{c}\text { RECEITA } \\
\text { ANUAL }\end{array}$ & $\begin{array}{c}\text { DESPESA } \\
\text { ANUAL }\end{array}$ & $\begin{array}{c}\text { GASTO } \\
\text { C/FESTAS }\end{array}$ \\
\hline 1768 & \multicolumn{2}{|c|}{39,37} & 40,65 \\
\hline 1769 & \multicolumn{2}{|c|}{50,39} & 45,07 \\
\hline 1770 & \multicolumn{2}{|c|}{37,80} & 41,06 \\
\hline 1771 & \multicolumn{2}{|c|}{49,60} & 38,75 \\
\hline 1772 & \multicolumn{2}{|c|}{41,56} & 41,83 \\
\hline 1773 & \multicolumn{2}{|c|}{-} & - \\
\hline 1774 & \multicolumn{2}{|c|}{30,30} & 37,88 \\
\hline 1775 & \multicolumn{2}{|c|}{38,00} & 41,30 \\
\hline 1776 & \multicolumn{2}{|c|}{38,52} & 43,52 \\
\hline 1777 & \multicolumn{2}{|c|}{24,69} & 31,50 \\
\hline 1778 & \multicolumn{2}{|c|}{-} & - \\
\hline 1779 & \multicolumn{2}{|c|}{33,33} & 46,46 \\
\hline 1780 & \multicolumn{2}{|c|}{30,89} & 31,67 \\
\hline 1781 & \multicolumn{2}{|c|}{-} & - \\
\hline 1782 & \multicolumn{2}{|c|}{31,94} & 41,07 \\
\hline 1783 & \multicolumn{2}{|c|}{25,69} & 30,83 \\
\hline 1784 & \multicolumn{2}{|c|}{23,64} & 24,53 \\
\hline 1785 & \multicolumn{2}{|c|}{52,56} & 47,67 \\
\hline 1786 & \multicolumn{2}{|c|}{44,09} & 48,24 \\
\hline 1787 & \multicolumn{2}{|c|}{42,06} & 47,37 \\
\hline 1788 & \multicolumn{2}{|c|}{49,45} & 50,00 \\
\hline 1789 & \multicolumn{2}{|c|}{-} & - \\
\hline 1790 & \multicolumn{2}{|c|}{66,23} & 55,43 \\
\hline 1791 & \multicolumn{2}{|c|}{36,90} & 37,35 \\
\hline 1792 & \multicolumn{2}{|c|}{59,52} & 59,52 \\
\hline
\end{tabular}

Fonte: AEAM Registro de Receitas e Despesasde da I NSC de Casa Blanca, 1739-1805, cod. L- $1^{9}$

Se as associações religiosas negras (onde supostamente as taxas de mortalidade eram mais altas, em função das condições de vida de seus associados) mandassem celebrar todas as missas que seus "compromissos" determinavam para cada irmão fal ecido, elas talvez tivessem que postergar as festas, ou fazêlas com menos solenidade, o que iria contrariar a cul tura religiosa vivida na época. Por isso é que elas se queixavam tanto do valor de tais ofícios, a ponto de d. frei M anuel da Cruz, primeiro bispo da Sé de Mariana, fixar os valores dos ofícios paroquiais da seguinte forma: 
Atendendo as representações que nos fizeram sobre os excessos dos emolumentos paroquiais, por cujo motivo se não faziam os ofícios pelas al mas dos falecidos, terá o Reverendo Pároco quatro oitavas de missa cantada; outras quatro por assistir ao ofício; ao Diácono e o Sub-Diácono por irem ao altar duas oitavas cada um, e por assistirem ao ofício mais duas. E pelas sepulturas fora da I greja se não dará esmola para a Fábrica,mas terá o Reverendo Pároco três quartos de oitava pela encomendação ( da alma do falecido) e uma oitava pelas duas missas (dedicadas às almas) ${ }^{10}$.

Não obstante este tabelamento dos preços dos ofícios religiosos, que poderia ter evitado distorções na cobrança dos mesmos por parte dos párocos, estes e as irmandades continuaram vivenciando no decorrer do século XVIII disputas em torno dos direitos paroquiais. M as, antes de prosseguir a apresentação delas, façamos uma pausa para discutir a questão das tensões entre os visitadores eclesiásticos e as confrarias negras por eles visitadas, em relação às missas dedicadas às almas do purgatório.

Para a I greja, o purgatório não só representava uma significativa fonte de renda (porque as missas dedicadas às almas, para queo processo de purgação delas fosse mais rápido, não eram celebradas gratuitamente), mas também uma base sobre a qual seu poder (ou sua presença) se fazia no imaginário (sistema de representações) das populações que estavam sob sua autoridade. Por isso, ela, através de seus agentes, repreendia as confrarias que não celebravam aquelas missas, porque sua autoridade (mais do que seus cofres) poderia ficar abalada caso tal desobediência se generalizasse.

Então, os escravos elibertos associados em irmandades religiosas vivenciaram elementos da cultura cristã além das devoções católicas que eles cultuavam em tal espaço?

A julgar a partir de al gumas solicitações que uns negros fizeram a um ca pelão mineiro durante o século XVIII, podemos perceber que al guns rituais sagrados cristãos faziam parte de sua vivência religiosa:

Dizem os Aplicados da Capela de Nossa Senhora da Conceição da Cachoeira do Brumado, filial da Freguesia de Nossa Senhora do Rosário do Sumidouro, que achando-se o Adro da mesma capela com pouca decência, o cercaram (para nele) não entrarem animais; e como no dito cerco compreende mais terra do que se acha benzida para o cemitério dos Escravos, querem que Vossa Excelência (episcopal) Ihefaça a graça conceder licença ao capelão, para este benzer a terra que acrescem dentro do dito cercado ${ }^{11}$. 
O verbo benzer, provavelmente, foi muito usado durante o Brasil escravista como expressão de uma vivência cultural que lançava mão de ritos sagrados para proteger o corpo, a alma, lugares e coisas. Benziam-se os animais, as casas, os cemitérios, ruas, as imagens de devoção, a pedra fundamental de uma construção, contra as doenças, etc. Naquele mundo em que os conhecimentos médicos e o seu exercício eram limitados,além das ervas,um dos poucos recursos disponíveis para a busca da cura das manifestações patogênicas corporais foi a fé. Esta era vivenciada no contexto patogênico através da reza, das promessas devocionais das romarias, da benzeção, entre outras. O s negros, de acordo com o grau de inserção na cultura cristã, utilizaram-se destes recursos, vivenciando em seus cotidianos as suas práticas, como forma de solucionar problemas imediatos causados pelas vicissitudes da vida.

Retornando à questão da relação dos negros com os mortos, dissemos que as tensões entre as mesas diretoras de suas irmandades e os visitadores diocesanos no que tange ao gasto "insuficiente", por parte dos negros, com as missas em intenção das almas do purgatório, pode ser explicada, por um lado, pelo fato de elas demandarem custos que inviabilizavam a satisfação integral da quantidade de missas previstas em compromisso, e por outro lado, pelo fato de tal atitude custar caro ao poder eclesiástico, caso ela se generalizasse. Além disso, uma outra questão nos ajuda a compreender o problema em torno daquelas tensões: os escravos e libertos não perderam, com o cativeiro, al gumas de suas her anças africanas relativas ao além, que eles recriaram na dinâmica da existência escrava.

Estes in divíduos vivenciavam uma complexa cultura de relação com os seus entes falecidos, a qual servia-Ihes como um fator de aproximação, isto é, uma referência para a ( $r$ e) construção de elos sociais, sobre os quais al gumas das faces de suas identidades se sustentavam. Nesse sentido, os negros praticavam alguns rituais de culto aos mortos, não compartilhados, de um modo geral, pelos cristãos. Em 1726, o bispo dom Antônio de Guadalupe, em visita à Capitania mineira, quando ela ainda estava vinculada ao Bispado do Rio de Janeiro, relatou que al guns escravos "faziam ajuntamento de noite com vozes e instrumentos em sufrágio de seus falecidos, ajuntando-se em algumas vendas, onde compram várias bebidas e comidas, e depois de comerem lançam os restos nas sepulturas"12. Através desse relato, podemos perceber que os negros vivenciavam rituais, a partir dos quais eles se relacionavam com os seus ancestrais de um modo diferente das referências do além cristão.

No início do século XIX, em visita ao Rio de Janeiro e M inas Gerais, Jean Baptiste $D$ ebret representou da seguinte forma um cortejo fúnebre de um rei africano tornado escravo no Brasil: 


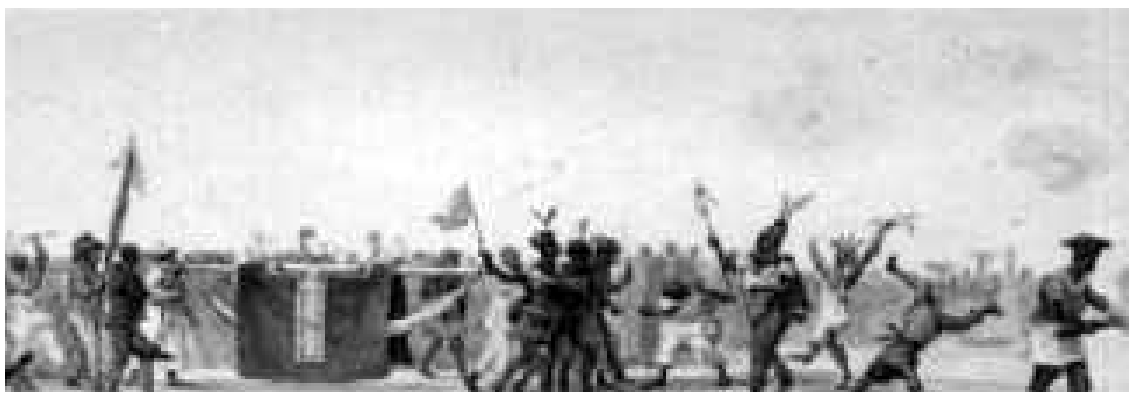

Sepultamento de um negro (Debret, Apud REIS, 1991, Capa).

Há neste registro pelo menos um símbolo cristão, a cruz que decora o pano utilizado para cobrir o morto, e várias manifestações que ajudaram José João Reis a concluir que a morte era uma festa no Brasil,sobretudo entre negros. Notem que há elementos nitidamente lúdicos em tal ritual, como o negro "plantando uma bananeira", e um outro com um instrumento de batucar.

Estes dois exemplos servem para demonstrar que se os escravos e libertos assimilaram (uns mais, outros menos, e uns outros nem um pouco) a noção do purgatório, mesmo que não gostassem de gastar muito dinheiro com a contratação dos ofícios religiosos, eles também vivenciaram algumas de suas heranças africanas, as quais recriaram no mundo do cativeiro o que tornou a relação deles com os mortos bem mais complexa e nuançada. Sendo assim, as tensões entre os representantes da I greja e as mesas diretor as de suas associações religiosas não po deriam ser simples resultados de conflitos financeiros, embora estes não devam ser ignorados, pois estava em jogo a necessidade de ambos os litigantes defenderem os seus cofres para as suas prioridades.

Feitas estas consi derações, retornemos à apresentação de outros exemplos de tensões entre as irmandades negras e a I greja, agora com um outro setor dela: o clero paroquial. Esse setor clerical tinha o direito de cobrar taxas (emolumentos) de seus paroquianos e das associações religiosas sediadas em sua aplicação relativas às missas em intenção das almas, aos sermões proferidos em festas, às missas cantadas durante solenidades devocionais, entre outros. Como os confrades contratavam capelões, os quais eram às vezes escoIhidos através de el eição, para a real ização de ofícios como ladainhas,missas dominicais, acompanhamento de mortos à sepultura, etc., eles tendiam a usar os seus contratados para a execução daquel as funções reivindicadas pel o pároco. Em torno disso e de outras questões surgiram atritos entre as confrarias negras eas paroquiais. 
Os irmãos da I rmandade de N ossa Senhora do Rosário de Itaverava, freguesia de Mariana, reclamavam ao bispo, no ano de 1743, que

(...) na eleição de capelão temos experimentado inconvenientes, nos opondo-se vários Eclesiásticos e ainda homens brancos, de tal sorte que ficamos preteridos nas elei ções; e queremos que Vossa Excelência Reverendíssima nos conceda faculdade para que em M esa, façamos eleição de capelão, e que neste não se interponha pessoa alguma, de qual quer estado equalidade que seja ${ }^{13}$.

Ao que parece, alguns senhores e eclesiásticos tentavam influenciar na escolha do capelão que conviveria com aquel es confrades no espaço de suas confrarias. Por quê? Talvez para controlar, cada um de acordo com seus interesses, esse espaço de solidariedade, devoção e lazer, onde os negros puderam reinventar sua existência entre uma jornada e outra das obrigações do cativeiro. No entanto, eles não aceitavam tal controle e agiam contra el e,solicitando ao bispo permissão para escolher seus sacerdotes a partir de critérios próprios, motivados pelos seus interesses.

Em 1748, o visitador M iguel de Carvalho de AImeida M atos, em visita ao Curral Del Rey, atual Belo Horizonte,antiga freguesia de Sabará,atendendo às solicitações do pároco local, determinou:

(...) aos administradores das capelas e capelões que não consintam abrir-se nelas sepulturas nem fazerem-se enterramentos sem beneplácito do Reverendo Pároco", justificando tal determinação pelo fato de "pelas distâncias desta Freguesia sucede fazerem-se al guns enterramentos de defuntos sem autoridade e ciência do Reverendo Pároco, ficando este assim prejudicado nos seus direitos paroquiais, e a I greja na sua fábrica ${ }^{14}$.

Anos mais tarde, em 1756, um outro visitador, Theodoro Ferreira Lacombe, em visita à mesma freguesia mencionada anteriormente, tornou a ordenar:

(...) que nenhum administrador de capelas ou outra pessoa consinta que nelas se abram sepulturas e se façam enterramentos sem licença do Pároco, sob pena de excomunhão maior e cinqüenta cruzados, e recomendo aos capelões, debaixo das mesmas penas, que proíbam que nas três capelas se façam festas com sermão sem especial licença do Reverendo Pároco, recomendando a observância da Pastoral do Excelentíssimo Reverendíssimo Bispo atual deste Bispado ${ }^{15}$.

Pelo visto, a distância e, conseqüentemente, a dificuldade do pároco em se fazer presente ostensivamente, de forma constante e planejada, continuaram favorecendo aqueles fregueses o não-cumprimento das normas eclesiás- 
ticas relativas à defesa dos direitos de cobrança paroquial de taxas por ofícios religiosos demandados pela população.

Neste mesmo período, os irmãos do Rosário do Alto da Cruz, cuja associação religiosa estava sediada na freguesia de Antônio Dias, situada em Vila Rica, diziam que a sua capela

(...) foi feita às expensas da devoção dos Fiéis, sem que para sua fatura, ornatos ou guizamentos concorresse em tempo al gum o Pároco desta Freguesia, e este costuma desfrutá-la querendo Ihe fábricas,sem acompanhar os Irmãos, e ainda sepulturas, sendo eles enterrados nesta própria capela,sem mais zelo ou caridade que o da sua ambição; e por ela não ser (sua) filial, se não pagará nada ao dito Pároco ou Fábrica,(...), pois tem mostrado a experiência as continuadas de sordens que os vigários fazem e promovem, tudo a benefício de seu interesse ${ }^{16}$.

Este documento, somado aos anteriores, indica que as tensões entre as paróquias e as confrarias negras em torno dos emolumentos devidos aos párocos er am recorrentes, podendo o seu desfecho se caracterizar por atitudes mais contundentes,tanto de um lado quanto do outro, como mostram as fontes. Este tipo de litígio atravesso u toda a segunda metade do século XVIII e, na transição deste para o XIX, já em pleno processo da crise do sistema colonial, ainda é possível detectá-lo. 0 clero paroquial da Freguesia de Nossa Senhora de Piedade da Vila de Barbacena, ao reclamar os seus direitos paroquiais, afirmou que:

(...) tem sido geral as Irmandades erigidas no Bispado de M ariana em aumentar os seus capelões no exercício dos ofícios eclesiásticos, pretendendo que sejam eles seu principal porta-voz, com exclusão dos que foram pelo Grão-M estre postos nas Paróquias (...) fazendo-se de odiosos, de perturbadores do sossego público e de rebeldes à sujeição dos Postos da Diocese paroquial ${ }^{17}$.

Pelo que foi visto, a relação entre a I greja e as irmandades negras nas M inas Gerais do período colonial teve em uma de suas faces a marca da tensão, devido aos interesses inconciliáveis que uma defendeu diante da outra, em torno de recursos financeiros (necessários para que ambas organizassem suas atividades) e da vivência religiosa (razão pela qual ambas existiram naquele período).

E isto pode ter ocorrido porque as festas devocionais tal vez tivessem sido de fundamental importância para os escravos e os libertos, como a (re) definição e a ( re) construção de relações de identidade e poder internos ao grupo, de forma que o destaque que tais festas receberam no orçamento geral de suas associações religiosas tivesse um sentido que transcendia até mesmos as expectativas dos artífices da ordem escravista, os quais muitas vezes pensa- 
ram que as manifestações lúdicas e de religiosidade daqueles indivíduos não passavam de meros folguedos, sem nenhum objetivo; o que não é verdade se invertermos o foco da análise, partindo agora das próprias motivações dos negros. Assim, poderemos perceber que, muito mais do que isso, os seus festejos não foram simples válvulas de escape do dia-a-dia, e sim um ponto de partida para a reinvenção de uma existência em que grassava a escravidão.

\section{NOTAS}

* M estre em História Social pela UFRJ professor de M etodologia da História ecoordenador do N úcleo deH istória Regional da UniversidadeVale do Rio D oce,G ov. Valadares-M G.

** Pesquisa feita com o apoio da CAPES, desde o tempo do PET na Universidade Federal de Ouro Preto (1993-96), cujo tutor foi a prof. dr. Renato Venâncio, até o M estrado na Universidade Federal do Rio de Janeiro (1998-2000) cuja orientação foi feita pela Profạ. Drạ. Celeste Zenha.

${ }^{1}$ AEAM , Livro de Contas de Receitas e Despesas do IN SRP do Itatiaia, Cod. M . 23, f. 33.

${ }^{2}$ AEAM , Registro de Receitas e Despesas da IN SR de Casa Branca 1739-1801, Cod. L-1,f.5.

${ }^{3}$ Idem, f. 2.

${ }^{4}$ Idem, f. 28.

${ }^{5}$ Idem, f. 89v.

${ }^{6}$ AEAM , Registro de Receitas e Despesas da INSR, SB eSE do Itatiaia,1730-1791, Cod.M 23, f. 34v.

${ }^{7}$ Idem, f. 33v a $78 \mathrm{v}$.

${ }^{8}$ Idem, f. 79.

${ }^{9}$ dem, f. 28 a 33.

${ }^{10}$ AEAM , Disposições Pastorais, 1750, Cod. F-22 eW-3, f. 3v.

${ }^{11}$ AEAM ,Cartas Avulsas de I rmandades Negras, Séc. XVIII.

${ }^{12}$ AEAM , Governos Episcopais (Avulsos).

${ }^{13}$ AEAM , Carta-Petição anexa ao Compromisso da IN SR deltaverava, 1743, Cod.N - 15,f.21.

${ }^{14}$ AEAM , Disposições Pastorais, 1748, Cod. F-22 eW-3, f. 21v.

${ }^{15}$ Idem, 1756

${ }^{16}$ APNSCOP, Compromisso da INSR do Alto da Cruz deVila Rica, Rolo 5B (microfilme).

${ }^{17}$ AEAM , Carta anexa ao Compromisso da IN SR de Barbacena, 1810, Cod. 35, f. 4. 